\title{
Business Climate Versus the Attraction of Direct Foreign Investments in Albania
}

PhD Dritan Shoraj

PhD Perparim Dervishi

Lecturer, Faculty of Economy, Department of Management, University of Tirana, Albania

Chair of Business Administration Department, Faculty of Economy, University of New York, Tirana, Albania.

\begin{abstract}
There are statistics that foreign direct investments (FDI) in Albania have significantly declined. Business climate and skill of policies to attract FDI in Albania has apparently not impacted the promotion of investments from foreign businesses. This study assesses the business environment disadvantages and the readiness and availability of foreign investors to take risks with their investments in a foreign market facing the business climate of the host country, as well as the skill or failure of the latter for long term cooperation. Some basic components of the business climate in Albania, impact and their attractiveness to foreign investors will be analyzed and assessed. The research methodology selected for this study is the quantitative one, where a number of about 100 CEO and administrators of medium and big foreign companies in Albania have been planned to be interviewed. The measuring instrument will be standardized and after data collection, a series of analyses will be built such as correlation, means, standard deviations, frequencies, Chi-square $(x 2)$ where the value $p>00.5$. Analysis of variables will be realized through SPSS program. The study will be closed with relevant conclusions and recommendations.
\end{abstract}

Keywords: foreign direct investments, business climate, fiscal policy, management.

\section{INTRODUCTION}

The rapid economic growth and integration in the European Union are listed among the key priorities in the Albanian government program and of the regional governments as joining the European family appears to be the final station for Albanian people and Balkans as a whole. Therefore, the main domestic policies over the last years have had a positivist approach to the economic liberalization and business climate improvement, leasing to better conditions for doing business in Albania and to attract foreign direct investments (FDI). We see such an overview in the doing business study conducted by the World Bank (2015). Albania had an obvious improvement over years in the alignment among countries. Practically, in 2014 Albania was classified at the $62^{\text {th }}$ position compared to the $108^{\text {th }}$ position of one year ago in 2013 , but the last year situation is worse, because Albania lost 35 positions and it is classified at the $97^{\text {th }}$ position. The law of foreign direct investments in Albania provides a favorable climate to attract foreign direct investments (FDI). Further, based on the Albanian legislation, there is no restriction regarding the entry of foreign investments and there is equal treatment with local and foreign investors.

On the other hand, it is noted that foreign direct investments (FDI) are highly instrumental to the generation of local investments to attract funds, facilitate the transfer of management skills and technological knowledge, expand local market competition, create modern employment opportunities, increase global market access to goods and export etc (Moosa, 2002). Accordingly, taking into account the importance and key role of FDI for the developing countries, the governments of these countries attempt to stimulate the FDI attraction, practicing various stimulation packages in fiscal policies but not only. Such reforms may create a friendly climate for foreign investors, with a view of minimizing or removing trade barriers and state involvement in business issues, attempting to provide mutual partnership between the government and investor, and without underestimating the competition level of other regional countries so that to make the country more attractive for foreign investors.

However, a number of empirical researches carried out in different countries show that development and implementation of reforms is an ongoing and inadequate process because other associated policies will be required to further improve the business climate and of investments in general (Navaretti and Venables, 2004). Readiness and availability of the 
governments to build appropriate infrastructure (Wheeler and Mody, 1992) have a positivist approach to fiscal and institutional policies, representing key factors for the developing countries, with a view of increasing the inflows of foreign investments (Henisz, 2000a, b).

Being a serious coherent issue for international companies and economics of the developing countries, it has given rise to our research study. Based on a quantitative empirical research, we will highlight some of the business climate components contributing to the attraction of FDI. The basic purpose of the study is to analyze the impact of business climate on the attraction of FDI, addressing the independent variables: corruption, fiscal policies and political stability. Hence, we will identify the correlational relationship between the dependent variable of business climate and independent variables of corruption, fiscal policies and political stability.

In close connection with theoretical and empirical studies, the present study is based on the research question of investigative character: Does the business climate (corruption, fiscal policies and political stability) impact the attraction of FDI in Albania?

The study hypotheses to be tested in the wake of this study are raised on the key components influencing the attraction of FDI in Albania. Null and alternative hypothesizes are determined as below:

$\mathrm{H}_{1} \rightarrow$ Corruption has a negative impact on the attraction of FDI.

$\mathrm{H}_{2} \rightarrow$ Fiscal policies influence the attraction of FDI.

$\mathrm{H}_{3} \rightarrow$ Political stability has an impact on the attraction of FDI.

\section{LITERATURE REVIEW}

There are wide empirical literature sources on the course followed by FDI investments in developing countries, and their impact on host countries. Yet, which are the reasons of business transfer or doing business in a foreign country?

Most of these studies highlight a series of main factors attracting foreign investors, such as the internal economic environment, market size and opportunity to establish an economy of scale (Mitra and Golder, 2002); quality of infrastructure, labor force cost, (Wheeler and Mody, 1992) economic opening, capital gains, political stability (Schneider and Frey, 1985), good governance (Globerman and Shapiro, 2002), macroeconomic stability, level of economic reforms, trade liberalization, heritage of natural resources, privatization method etj. Garibaldi etc, (2001), namely, the business and investment climate in general. All these factors, according to Rugman (1981), constitute advantages of both main groups:

a) specific sustainable advantages of the company or "driving force" as we would refer to the country of origin. Specifically, the company skill, capacity or additional potential to expand its activity abroad such as technology, various knowledge, management or marketing skills and other assets; and

b) specific advantages of the host country or "force of gravity" of the host country, in our opinion, include all specific advantages afforded by the host country such as natural resources, quality and quantity of labor force or otherwise referred as human assets, labor force cost, cultural factors, corruption level, tariff and non-tariff barriers, fiscal policies etc. Based on the specific qualities of the host country or to put it differently "attributes of the host country" are determinant in the FDI inflow (Smith, 1981). On the other hand, empirical researches demonstrate that FDI investments generate a positive impact on the economic growth of the host countries (Duttaray, Dutt and Mukhopadhyay, 2008).

A number of scientific studies have treated with high priority the role of business climate on the attractiveness of FDI investments in the developing countries as an instrument of globalization increasing the equality of the distribution of income and goods as a whole (Pica and Mora, 2011). Based on the study conducted by Kinda (2010), in many countries of the world it appears that serious limitations in relation to FDI attraction are financing restrictions, institutional concerns, corruption and physical problems of infrastructure (Asiedu, 2002) etc. Further, the studies of Kaufman etc (1999) and of many other researchers conclude that the most important indicators of FDI attraction are political stability, government's effectiveness, regulatory burden or fiscal policies, law enforcement, corruption level and labor force cost (Wheeler and Mody, 1992). 


\section{II.1 Corruption}

Corruption is a social problem, a lack of rules, distortion of social norms and values required for the normal functioning of a free market economy (Primorac and Smoljić, 2011). Corruption is a behavior that constitutes a deviation of normal performance of public duties for personal profit or abuse of office by public officials for personal gain, or of a particular group (Bardhan 1997; Bardhan, 2002), impacting the economic development in general (Abed and Gupta, 2002; Easterly 2001), involving additional cost of public or private spending (Kurtzman etc, 2004), in order to create a less favorable environment for FDI and not only. Based on a number of scientific studies, corruption has unequal access to treatment of different groups of interest (Gupta etc., 2002), creates additional costs, escalating prices (Anand etc., 2005), is a serious barrier to economic prosperity of the country (Mauro, 1995; Mauro, 2002) for the access to public goods (Mauro 2002) etc.

Apart from the transaction costs in economy, corruption involves much higher costs in the form of artificial distortions of economy as a ground of opportunistic pragmatist approaches of the corrupt officials. These costly expenses will have to be latter added up through the increase of taxes (Rose-Ackerman 1997), and curtailing of expenses or public investments with a direct impact on the economic growth and increase of inflation etc (1992).

Accordingly, based on the above literature, many researchers have concluded that corruption is a serious obstacle to the attraction of foreign direct investments. Nevertheless, there are other researchers who admit that corruption may have a positive impact on FDI attraction (Egger and Winner, 2003; 2005). We will see below how corruption will impact on the Albanian economy.

\section{II.2 Fiscal policies}

Many researchers empirically draw the conclusion of relations between taxes and economic growth, as well as the attraction of foreign investors in particular (Dzambaska, 2013). Hence, changes in the fiscal burden, by facilitating it, produce a significant effect in the increase of number of local business on one hand and they represent a positive instrument to enhance attractiveness and FDI attraction on the other hand (Kaufman etc, 1999; Gropp and Kostial, 2000). A healthy investment climate may sharply reduce transaction costs of the enterprises and the opposite occurs in the increase of doing business cost to the extent that foreign investors do not any longer desire a specific market, notwithstanding the other benefits that may be potentially provided by this market.

The governments often decide on fiscal facilities such as the reduction of tax rate on the corporate revenues to attract FDI investments (Hines, 1999), in strategic sectors or specific regions. This tactic is basically applied by developing countries and economies of the countries in transition. There are many countries that have applied these fiscal incentives, including Albania, which has recently approved six strategic sectors and approval of a free economic zone offering fiscal facilities and not only for the purpose of FDI attraction (relevant law, 2015).

Macroeconomic stability, the sustainability of fiscal policy are considered a key component in decision-making and attractive to foreign investors (Demekas etc. 2007). Therefore, many researchers believe that the policies of the host country are a determinant factor in FDI decision-making. An open market policy that promotes macroeconomic stability, stimulates fair competition on one hand and on the other hand strongly encourages private sector development, is obviously very attractive for absorption of investment and not only. Further, Mitchell (2002) concludes that fiscal competition between countries leads to a reduction of the fiscal burden as foreign investors may transfer their businesses to countries with lower tax burden. Therefore, in this way fiscal competition helps to reduce fiscal burden and FDI absorption (Mitchell, 2002). Furthermore, Diamond and Mirrlees (1971) recommend that small economies should avoid taxation of income received by foreign investors to attract more FDI.

\section{II.3 Political stability}

Numerous scientific researchers have found out that political and economic risks seriously prevent the entry of FDI, namely, the political instability creates an uncertain economic environment both at present, and in the longer term to absorb new investments (Barro, 1991; Corbo and Schmidt- Hebbel, 1991). Political stability and sustainable policies of trade opening during the transition of developing countries tend to attract more foreign investors (Campos and Kinoshita, 2003) because it is a good opportunity of expansion for FDI, while the latter are instrumental to the reduction of unemployment and economic growth (Greenaway etc, 2002). 
Countries characterized by political stability are commonly associated with democratic institutions and they are supposed to have a positive impact on the entire economy through the process of checks and balance for state administration (Harms and Ursprung 2002; Leavell etc., 2004). Hence, as it appears from the above literature, political stability provides a positive contribution in attracting FDI, but there are other researchers who oppose this line of thought. According to them, they may have a negative effect on FDI investment, since foreign investors may be able to receive better incentives and treatments by autocratic regimes and countries that do not have adequate political stability (Bellos and Subasat, 2012) .

\section{RESEARCH METHODOLOGY}

This study is built upon the positivist approach with objective ontological position, where the social reality is existent and may be studied independently from us as researchers (Bob Matthews and Liz Ross, 2010). Knowledge on the phenomena of business climate of the employees FDI attraction is based on what we as researchers may observe and record from the reality, being objective in relation thereto, without impact on data and survey respondents.

In order to prove the hypotheses, present data with easily observable values are used, which are obtained from opinion polls of 94 CEOs and managers of medium and large businesses in Albania. All data are coded and subsequently analyzed by the statistical program SPSS (Statistical Package for the Social Sciences, version 20). Average value, standard deviation, frequency and other statistical data have described the characteristics of the study on population. Testing of hypothesis is accomplished through Chi-square test $(X 2)$, where the proper statistical level is accepted at $p<.05$.

We have established contacts with all human resources departments of some medium and large companies of FDI (Foreign Direct Investments) operating in Albania, from where we were able to get the opinions of 94 top management leaders. Of those interviewed, 27 were women and 67 men. Sampling was randomly made, by calculating the number of foreign companies operating in Albania. In case a manager refused to participate in the survey, another manager showing interest for the survey was selected.

\section{DATA ANALYSIS}

\section{Some other demographic data}

We will present some demographic data of this study through related charts. The first chart provides related data regarding year of activity of foreign companies operating in our country. From 94 participant companies in the study, 54 of them are Ltd companies; 28 companies are joint-stock companies (JSC); representative branch office of a foreign company, or tax representatives, and 12 other companies.

Based on the data collected, 24 of them have a production activity, 15 are wholesalers and retail companies, 46 service providers, and 9 other different activities.

In order to evaluate whether Albania has increased its foreign investments during the years of the loan, the chart below provides survey data, which results are that there is a decrease in absorption of foreign investments in the country in recent years is; respectively, according to chart data in recent years, we have by 2010 two companies that began its activity in Albania, in 2011 only one company, and in 2014 only 2 companies. But, if we refer to data coming from the Bank of Albania, we see that during 2014 we have a decline in foreign direct investment by $15 \%$, compared with a year ago, (Bank of Albania, 2015).

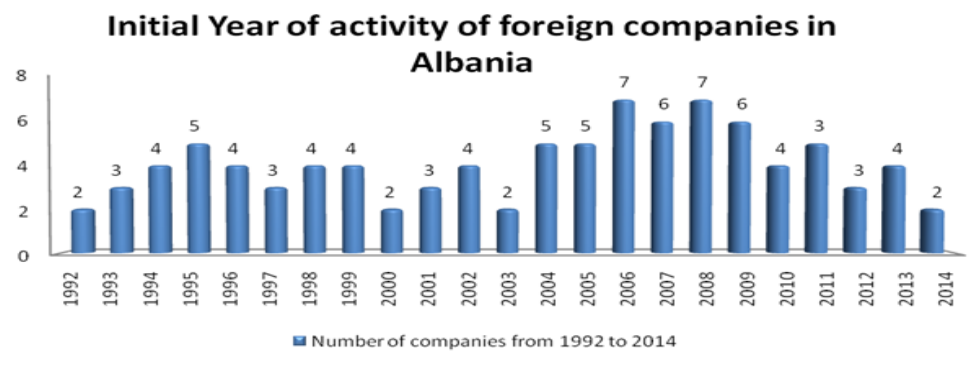

Chart No.1: Initial Year of Activity of Foreign Activities in the Country. 
Some of the problems encountered by the respondents in the Albanian business environment are presented in the chart below. They evaluated, according to their judgments and opinions, the issues listed in the chart below, with a measured ascending scale from 1 to 5 , where a weighted average is presented for each question (Figure No. 4). The assessment is made as follows: from $1=$ It is not a problem, to $5=$ It is a very serious problem .

\section{Problems of the business community in Albania}

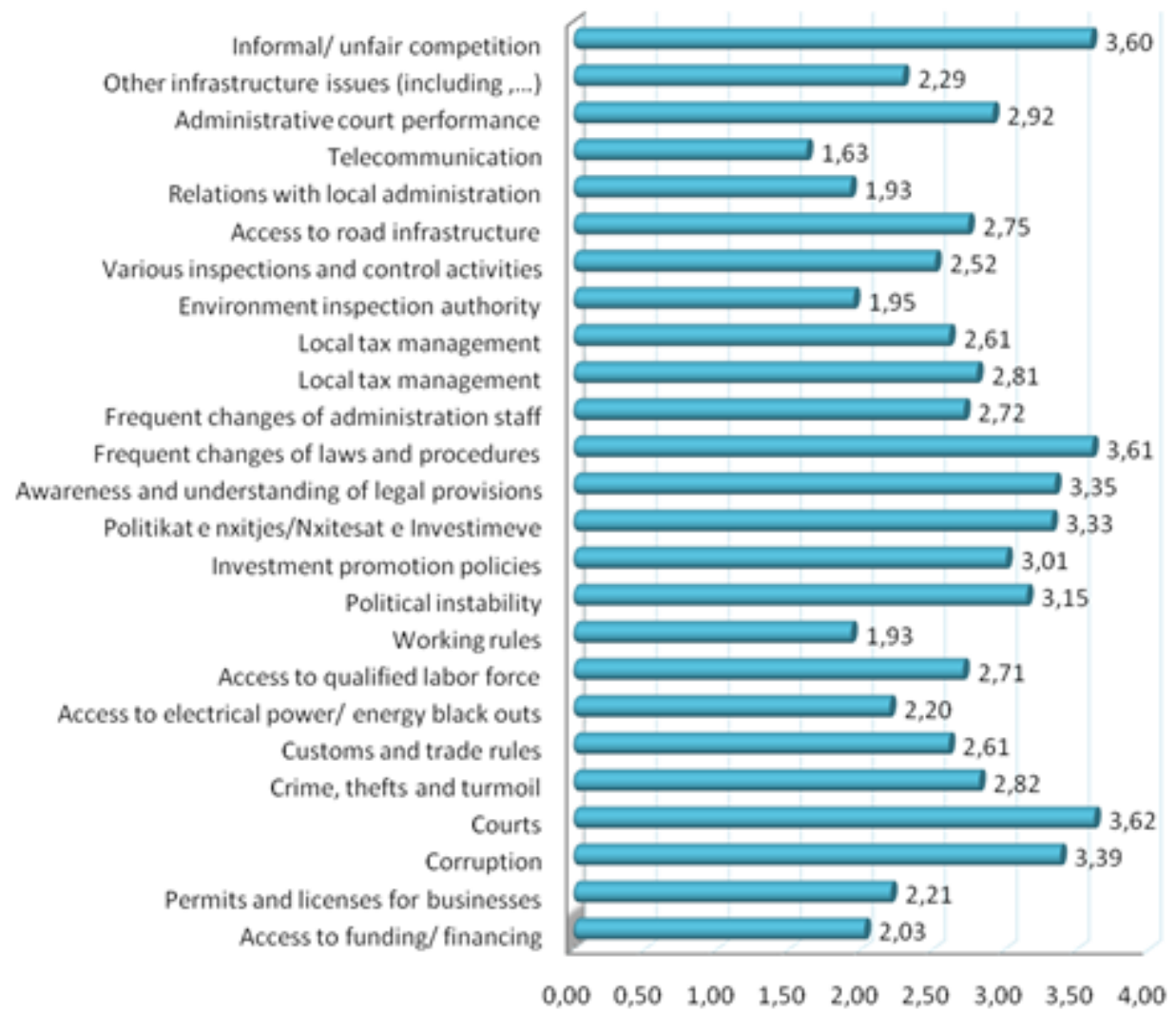

$\square$ an average from a lower 1 to a higher 5

Chart no.2: Weighted average of opinions on business environment issues in Albania.

The hypothesis of this study was established based on the research question, where we first hypothesis was $\mathrm{H} 1$ : Corruption adversely affects the promotion of foreign investments. According to the bivariate correlation analysis there is a negative relationship between the two variables, where the growth of corruption in Albania has increased the possibility of an unfavorable business climate for foreign investments in the country. Practically, the value of the correlation coefficient between the two variables is -0.125 and the level of reliability (alpha observed) is 0.0247 lower than $5 \%$, which means that there is a statistically stable positive relationship between the two variables of the study.

Even in the case of testing of the second hypothesis/ assumption; $\mathbf{H 2} \rightarrow$ Political stability affects the promotion of foreign investments (FDI), it was tested the possible relationship between two variables by means of the bivariate Parsons' correlation analysis. The results of the data show that there is a positive relationship between the two variables, 
where the increase of the variable of the level of political stability is associated with the increase of the possibility that Albania is considered with a favorable climate for foreign direct investments, and the coefficient of the correlation in this case is 0.149 . The conclusion of this analysis is a positive relationship, statistically stable, between these two variables, where the level of security is 0.047 , which is lower than $5 \%$ (alpha observed $<5 \%$ or $p<.05$ ). The graphic form below presents the value of the coefficient of correlation between the independent variables, corruption and political instability, and the dependent variable such as FDI.

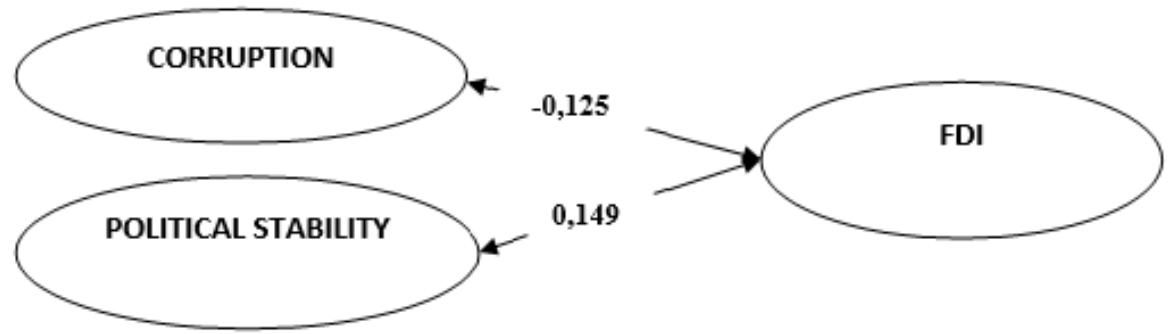

Fig No.1: Corelational relations between the variables of corruption, political stability and FDI

As for the third hypothesis of this study, $\mathrm{H3}$, fiscal policies affect the promotion of foreign investments in the country, based on an bivariate analysis, the correlation relations between the variables of this hypothesis were tested, where FDI is taken for analysis as an dependent variable, and some fiscal policy components are taken as independent variables of the country. As shown in the figure below, we observe that all independent variables have negative relationship with the dependent variable or $\mathrm{FDI}$, and in all cases, it is clear that the value of the level of security is lower than $5 \%$ (alpha observed $<5 \%$ or $p<.05)$. This analysis showed that there is a negative relationship statistically stable between the variables. The following figure shows the relevant values of the correlation coefficient for each case of the scheme

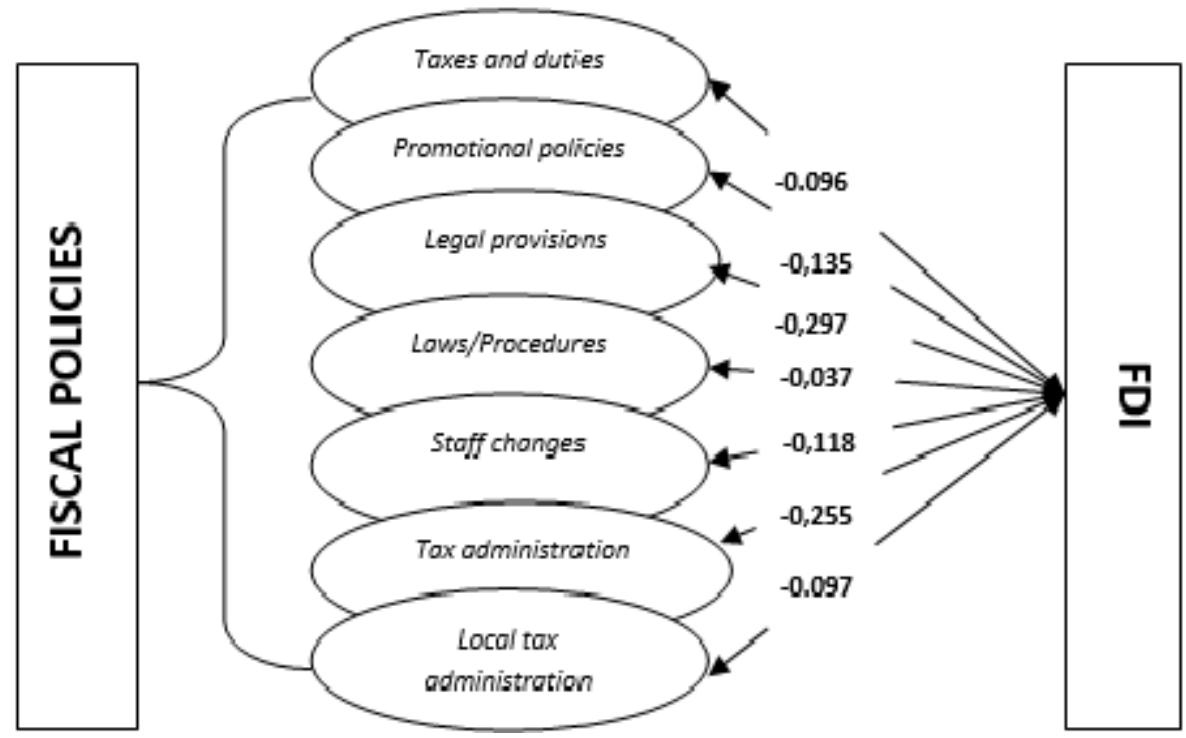

Fig no.2: Corelational relationship between the variables of fiscal policies and FDI in Albania. 


\section{Testing of hypotheses through hi-square test}

Through Chi-Square test, analysis of the three hypotheses of this study to prove the statistical stability and the security level (alpha observed $<5 \%$ or $p<.05$ ) was conducted. For the first hypothesis, two main variables such as corruption and the FDI were taken for analysis and as resulted from this analysis, the data showed that for the value of the observed Chisquare test of 44.411 , with $\mathrm{df}=24$, and a security level lower than $5 \%$, which in this case is 0.007 , it is concluded that this hypothesis is confirmed, so it is statistically stable. With the same model of analysis, the relationship between the variables of the second hypothesis, namely variables of political stability and FDI, was tested, which results for the observed Chisquare test value of 34,405 , the degree of freedom $\mathrm{df}=24$, give a value of the level of security again lower than $5 \%$, and we can consequently admit that the hypothesis is confirmed even in this case, so it is statistically stable.

Last hypothesis, as shown in the summary table of the chi-square test, consisting of a number of independent variables such as: levels of taxation, investment promotion policies, clarity and understanding of the legal provisions and tax procedures, frequent staff changes in administrative, tax management, local taxes management, compared with the dependent variable of FDI. In all cases, the analysis of test chi-square test showed that the level of security is lower than $5 \%$, which means that the hypothesis is verified and that there is a stable statistic relation between the two variables (refer to table no 1).

\begin{tabular}{|c|c|c|c|c|}
\hline Hypothesis & Pearson Chi-Square Tests & Value & df & $\begin{array}{l}\text { Asymp.Sig } \\
\text { (2-sided) }\end{array}$ \\
\hline $\mathrm{H}_{1}$ & Corruption ${ }^{*}$ Business Climate & $44.411^{\mathrm{a}}$ & 24 & 0.007 \\
\hline $\mathrm{H}_{2}$ & Political Instability * Business Climate & $34.405^{a}$ & 24 & 0.028 \\
\hline \multirow{7}{*}{$\mathrm{H}_{3}$} & Taxes and duties * Business Climate & $32.053^{a}$ & 24 & 0.021 \\
\hline & Promotional policies* Business Climate & 41.307 & 24 & 0.014 \\
\hline & Legal provisions * Business Climate & 41.321 & 24 & 0.018 \\
\hline & Laws/Procedures * Business Climate & 42.006 & 24 & 0,011 \\
\hline & Staff changes ${ }^{*}$ Business Climate & 44.303 & 24 & 0.009 \\
\hline & Tax administration* Business Climate & 42.704 & 24 & 0.032 \\
\hline & Local tax administration * Business Climate & 43.621 & 24 & 0.019 \\
\hline
\end{tabular}

Table No.1: Chi-Square test for three study hypotheses

\section{CONCLUSION}

Results of the survey show that there is a decrease of foreign direct investment (FDI) in Albania during the recent years, and namely in 2014 there is a decrease of FDI in Albania by 15\%, compared with a year ago.

Foreign companies operating in our country are mainly Itd companies (limited liability company) with $44 \%$, followed by joint stock companies with $29 \%$, and representative offices with $16 \%$, and the remaining $11 \%$ are various. Among them, it is worth mentioning that $26 \%$ are mainly focused in manufacturing, $50 \%$ are service oriented; $15 \%$ is focused on wholesale and retail sale in the local market, and $8 \%$ have different activity.

Some serious problems identified by foreign investors in Albania are as follows: the informal economy and unfair competition, which are evaluated with 3.6 / 5 points (3,6 out of 5); frequent changes in tax laws and procedures, evaluated at 3.61 / 5 ; another element negatively affecting the absorption of foreign investments are the courts 3,62 / 5 ; high corruption in state administrations which is $3.39 / 5$, and many other elements which are shown in chart No.2.

Based on the analysis of Pearson's correlation, the first hypothesis H1: Corruption adversely affects the promotion of foreign direct investments (FDI) is confirmed. According to the correlation bivariate analysis, there is a negative relationship between the two variables, which means that with an increase of corruption in Albania, FDI on the country decreases. The same conclusion is also reached through the analysis of Chi-Square test, which showed that for the value of chi-square observed test of 44.411 with $\mathrm{df}=24$, and a level of safety lower than $5 \%$, it is 0.007 , so we reach the conclusion that hypothesis $\mathrm{H} 1$ is statistically stable. 
The second hypothesis, $\mathbf{H} \mathbf{2} \rightarrow$ Political stability affects the promotion of FDI. Based on the analysis of Pearson's bivariate correlation, the relationship between these two variables is tested, which resulted in a positive relationship between the two variables, where the increase of the variable of political stability is followed by an increase of the possibility of a favorable climate for foreign investments in Albania. The analysis confirmed that there is a statistically stable positive relationship between these two variables, where the level of security is 0.047 , which is lower than $5 \%$ (alpha observed $<5 \%$ or $p<.05$ ). Even through Chi-Square test, the $\mathrm{H} 2$ hypothesis is confirmed, as for value of the observed Chi-square test of 34,405 and degree of freedom $d f=24$, the value of the level of security is again lower than $5 \%$.

The third hypothesis of this study is $\mathrm{H} 3 \rightarrow$ fiscal policies affect the promotion of foreign investments in the country. Based on the analysis of Pearson's bivariate correlation it is confirmed a statistically stable negative relationship between fiscal policy variables (unsustainable) and foreign investments.

We draw the same conclusion through the analysis of Chi-Square test. It followed that in all cases the security level is lower than $5 \%$, implying that there is a stable statistical relationship between the two variables, namely the hypothesis $\mathrm{H} 3$ is proven.

In conclusion, based on the data results of foreign investors carrying on their activity in the Albanian territory, it follows that the main factors impacting the attraction of foreign investments are: low corruption level, political stability and fiscal sustainable policies.

\section{REFERENCES}

[1] Abed, G.T., and S. Gupta. 2002. Governance, Corruption, \& Economic Performance. Washington, DC: International Monetary Fund.

[2] Anand V, Ashforth B.E, and Joshi, M. (2005). Business as usual: the acceptance and perpetuation of corruption.

[3] Asiedu, E. (2002) "On the Determinants of Foreign Direct Investment to Developing Countries: Is Africa Different?" World Development, vol. 30(1), pp. 107-118.

[4] Bardhan, P. 1997. "Corruption and Development: A Review of Issues." Journal of Economic Literature 35, no. 3: $1320-1346$.

[5] Bardhan, P. 2002. "Decentralization of Governance and Development." Journal of Economic Perspectives 16 (4): 185-205.

[6] Barro, R. (1991). Economic Growth in Cros Section of Countries. Quarterly Journal of Economics, 106, 407444.

[7] Bellos, S., and T. Subasat. 2012. "Governance and Foreign Direct Investment: A Gravity Model Approach." International Review of Applied Economics 26 (3): 303-328.

[8] Bob Matthews dhe Liz Ross, 2010.

[9] Campos, N., and Y. Kinoshita. 2003. "Why Does FDI Go Where It Goes? New Evidence from the Transitional Economies." Working Paper no. WP/03/228, International Monetary Fund, Washington, DC.

[10] Corbo, V., \& Schmidt-Hebbel, K. (1991). Public Policies and Savings in Developing Countries. Journal of Development Economics, 36, 89-115.

[11] Cukierman, A.; S.B. Webb; and B. Neyapti. 1992. "Measuring the Independence of Central Banks and Its Effect on Policy Outcomes." World Bank Economic Review 6, no. 3: 353-398.

[12] Dimitri G. Demekas, Balázs Horváth, Elina Ribacova \& Yi Wu. (2007). "Foreign Direct Investment in European Transition Economies-The Role of Policies," 35 J. Comp. Econ. 369.

[13] Duttaray, M., A. Dutt, and K. Mukhopadhyay. 2008. "Foreign Direct Investment and Economic Growth in Less Developed Countries: An Empirical Study of Causality and Mechanisms." Applied Economics 40 (15): 1927. 
[14] Dzambaska, E. (2013). "Empirical Analysis Of Fdi And Tax Incentives On The Economic Growth In The Republic of Macedonia", Economic Development No.3/2013 p.103-127.

[15] Easterly, W. 2001. The Elusive Quest for Growth: Economists' Adventures and Misadventures in the Tropics. Cambridge: MIT Press.

[16] Egger, P., and H. Winner. 2003. "Does Contract Risk Impede Foreign Direct Investment." Swiss Journal of Economics and Statistics 139, no: 2: 155-172.

[17] Egger, P., and H. Winner.. 2005. "Evidence on Corruption as an Incentive for Foreign Direct Investment." European Journal of Political Economy 21, no. 4: 932-952.

[18] Garibaldi, P., N. Mora, R. Sahay and J. Zettelmeyer, "What Moves Capital to Transition Economies?", IMF Staff Papers, vol. 48 (Special Issue), pp. 45-109.

[19] Globerman, S., and D. Shapiro. 2002. "Global Foreign Direct Investment Flows: The Role of Governance Infrastructure." World Development 30 (11): 1898-1919.

[20] Greenaway, D., W. Morgan, and P. Wright. 2002. "Trade Liberalization and Growth in Developing Countries." Journal of Development Economics 67: 229-244.

[21] Gupta, S., H. Davoodi., and R. Alonso-Terme. 2002. "Does Corruption Affect Income Inequality and Poverty?" Economics of Governance 3, no. 1: 23-45.

[22] Harms, P., and H.W. Ursprung. 2002. "Do Civil and Political Repression Really Boost Foreign Direct Investments?" Economic Inquiry 40, no. 4: 651-663.

[23] Henisz, J.W. (2000). "The Institutional Environment for Economic Growth," Economics and Politics 12 (2000a):1-31.

[24] Henisz, J.W. (2000). "The Institutional Environment for Multinational Investment," Journal of Law,Economics and Organization 16 (2000b):334-64.

[25] Henisz, J.W. and Delios A. 2001. Uncertainty, imitation, and plant location: Japanese multinational corporations, 1990-1996. Administrative Science Quarterly 46(3): 443-475.

[26] James R. Hines, Jr. "Lessons From Behavioural Responses to International Taxation,"52 Nat'I Tax J. 305 (1999).

[27] Kaufmann, D.; A. Kraay; and P. Zoido-Lobatón. 1999. "Governance Matters.” Policy Research Working Paper no. 2196, World Bank, Washington, DC.

[28] Kinda, T. 2010. "Investment Climate and FDI in Developing Countries: Firm-Level Evidence." World Development 38, no. 4: 498-513.

[29] Kurtzman J, Yago G, Phumiwasana T. 2004. The global costs of opacity. MIT Sloan Management Review 46(1): 38-44.

[30] Mauro, P. 1995. "Corruption and Growth." Quarterly Journal of Economics 110 (3): 681-712. Mauro, P. 2002. "The Persistence of Corruption and Slow Economic Growth." Working Paper no. WP/02/213, International Monetary Fund, Washington, DC.

[31] Mitchell. J, D. (2002). "The Global Tax Police: European Tax Harmonization Is a Smokescreen to Raise Taxes,". available at http://capitalismmagazine.com

[32] Mitra D, Golder PN. 2002. Whose culture matters? Near market knowledge and its impact on foreign market entry timing. Journal of Marketing Research 39(3): 350-365.

[33] Moosa, I. (2002). Foreign Direct Investment: Theory, Evidence and Practice, New York: Palgrave.

[34] Navaretti, B. G. and A. Venables. (2004). Multinational Firms in the World Economy, Princeton, NJ: Princeton University Press. 
[35] Peter A. Diamond \& James A. Mirrlees. (1971). "Optimal Taxation and Public Production II: Tax Rules," 61 Am. Econ. Rev. 261.

[36] Pica, G., and J. V. R. Rodríguez Mora. 2011. "Who's Afraid of a Globalized World? Foreign Direct Investments, Local Knowledge and Allocation of Talents." Journal of International Economics 85 (1): 86-101.

[37] Primorac, D and Smoljić, M. (2011). "Impact of corruption on foreign direct investment", Megatrend Review. Vol. 8 (2) 2011: pp. 169-190.

[38] Reint Gropp and Kostial, K. (2000). "The Disappearing Tax Base: Is Foreign Direct Investment Eroding Corporate Income Taxes?" ECB working paper no. 31., available at http://papers.ssrn.com/sol3/papers.cfm?abstract_id=355624.

[39] Rose-Ackerman, S. (1997). "The Political Economy of Corruption in Kimberly. Peterson Institute of International Economics http://www.iie.com

[40] Rugman, A.M. (1981). Inside the Multinationals: The Economics of Internal Markets (New York: Columbia University Press)

[41] Schneider, F., \& Frey, B. (1985). Economic and Political Determinants of Foreign Direct Investment. World Development, 13(2), 161-175.

[42] Smith, D. M. 1981. Industrial Location: An Economic Geographical Analysis. 2nd Ed. NewYork: John Wiley.

[43] Wheeler, D. and Mody, A. (1992) "International Investment Location Decisions: The Case of US Firms," Journal of International Economics, vol. 33, pp. 57-76

[44] www.bankofalbania.org

[45] www.worldbank.org/en/country/albania 